\title{
G Acknowledgments
}

My sincere thanks go to Prof. Bardo Fassbender who not only delivered the first expert opinion (Erstgutachten) but also proved a constant source of inspiration and encouragement. To him I owe more than he probably realizes. I am also deeply grateful to Prof. Astrid Epiney and Prof. Daniel Thym for having provided the other two expert opinions.

A journey of more than five years concludes with this book. It is up to the reader to judge whether the effort made to come to the end of this journey brings 'the greatest possible freedom' any closer. It is, however, subject to no doubt whatsoever that this book could not have been realized without the steady support and enouragement of a number of persons. To them go my heartfelt thanks. In roughly chronological order they are: Prof. em. Daniel Thürer, who had supervised my doctoral thesis, for encouraging me to continue with a Habilitation and continuously supporting me during the time; Prof. Oliver Diggelmann for his open eyes and ears, generous support, and frank advice at critical junctures; Prof. Thomas Gächter for supporting my grant applications; Prof. Hans-Peter Folz for welcoming me spontaneously when I one day wandered into the offices of the international lawyers at LMU Munich; Prof. Peter M. Huber and Prof. Rudolf Streinz for generous hospitality at LMU; Prof. Christian Walter for generously hosting me for a number of years at his chair and institute at LMU, for offering motivation, inspiration, intellectual discourse, and a quiet place to work without ever asking for anything in return; Dr. Helmut Aust, Dr. Benedikt Pirker, Prof. Sebastian Unger, and Dr. Antje von Ungern-Sternberg for the friendship and support without which it is impossible to go through a Habilitation; the many dear colleagues at LMU, including Prof. Ino Augsberg, Dr. Gebhard Bücheler, Ute Freitas, Dr. Daniel Fröhlich, Franka Fruhstorfer, Dr. Martin Heidebach, Dr. Albert Ingold, Prof. Daniel Kahn, Carolin König, Prof. Sophie Lensky, Stephan Lorentz, Dr. Walther Michl, Prof. Florian Möslein, Dr. Laura Münkeler, Ingeborg Neber-Germeier, Dr. Donald Riznik, Dr. Meinhard Schröder, Christine Schuhbeck-Schmidt, Prof. em. Bruno Simma, Paulus Suh, Markus Vordermayer, Prof. Ferdinand Wollenschläger, Quirin Weinzierl, and Dr. Markus Zöckler; Prof. Christoph Frei and Prof. Dirk Lehmkuhl for introducing me to University of St. Gallen (HSG) and for continuous support and friendship; Prof. Bernhard Ehrenzeller, Prof. Roland Kley, Prof. Markus MüllerChen, and Prof. Benjamin Schindler for invaluable advice and encouragement at the right moment; Dr. Andrew Walton, Dr. Michael Waibel, and Dr. Oliver Westerwinter for support and friendship; the many dear colleagues and friends at HSG, including Prof. Carl Baudenbacher, Prof. Christine Benesch, Dr. Andreas Böhm, Samuel Cobbi, Prof. James Davis, Dr. Daniela Engelmann, Martina Flockerzi, Sabine Greiser, Prof. Lukas Gschwend, Silvio Hänsenberger, Prof. Peter Hettich, Michèle Klarer, Dr. Katrin Krehan, Theresia Langosz, Moritz Meyer, Dr. Simon Planzer, Dr. Roland Portmann, Anita Samyn, Prof. Mark Schelker, 
Gabriela Schmid, and Prof. Isabelle Wildhaber; Dr. Jenö und Irène Stähelin for generously supporting my stay at Harvard and for generously offering the best quiet place to write a book; Prof. William Alford for generously hosting me at Harvard; and Prof. Florent Thouvenin for a great time at Harvard and elsewhere. I am also deeply grateful to Dr. Valentin Zellweger, Marianne Pfister, Dr. Malcolm Mac-Laren, and Fredrik von Bothmer who have continuously encouraged and motivated me for a number of years now - sometimes perhaps without noticing it themselves.

Anybody who has ever been involved in a Habilitation knows that it cannot be done without the steady support, patience, understanding, and encouragement of family and friends. Barbara, Lotti, Kaspar, Sue, and Mike generously provided all this and more than anyone could ever ask for; so did Martin, Anna, Leonhard, and in particular Jonathan. It is to them I am most grateful.

Finally, my thanks go to the Swiss National Science Foundation and the University of Zurich for supporting me with generous grants and to Emil-ZauggFonds at HSG for supporting the publication of this book with a generous contribution. 